\title{
Effects of Ozonated Water on Storage Life and Postharvest Quality of Iranian Table Grape (cv. Bidaneh Qermez)
}

\author{
Mahsa Geransayeh \\ Former MSc Student, Azad University of Tehran, Science and Research Branch, Tehran, Iran \\ Tel: 98-912-687-9912 E-mail: m.geransayeh@yahoo.com \\ Younes Mostofi (Corresponding author) \\ , Associate Professor, University College of Agriculture \& Natural Resources \\ University of Tehran, Karaj, Iran \\ Tel: 98-912-501-0495_E-mail: ymostofi@ut.ac.ir \\ Vahid Abdossi \\ Assistant Professor, Azad University of Tehran, Science and Research Branch, Tehran, Iran \\ Tel: 98-912-234-0791 E-mail: abdossi@srbiau.ac.ir \\ Mohammad Ali Nejatian \\ Assistant Professor of Agricultural Research, Education and Extension Organization. Quazvin, Iran \\ Tel: 98-912-381-6930_E-mail: nejatianali@yahoo.com
}

Received: April 25, 2011

Accepted: May 16, $2011 \quad$ Online Published: December 21, 2011

doi:10.5539/jas.v4n2p31

URL: http://dx.doi.org/10.5539/jas.v4n2p31

\begin{abstract}
Grape as a perishable fruit is susceptible to fungal infection especially Botrytis cinerea, as an agent of gray mold, and berry dehydration. There are limitations in use of synthetic chemical compounds to control postharvest losses in grape and other fruits. The aim of this study was the evaluation of non-chemical and safe methods for this purpose. Therefore, ozone soluted at $0.3 \mathrm{ppm}$ concentration with three treatment times $(5,10$ and $15 \mathrm{~min})$, in water was applied on 'Bidaneh Qermez' grape cultivar. Qualitative characteristics (decay, vitamin C, reducing sugars, weight loss, berry abscission, dehydration, cracking and sensory analyses) were evaluated. The results showed that treated fruits with ozone had lower decay percentage, weight loss, berry dehydration, abscission, cracking and higher reducing sugars and storage quality compared to controls. As a general result, ozone treatment caused lower decay incident and longer storability.
\end{abstract}

Keywords: Ozone treatment, Maintain quality, Shelf-life, Table grape

\section{Introduction}

Quality loss is a normal process during storage, but the level of degradation depends on storage conditions and the technologies used (Hulea, et al., 1982; Mari, et al., 2003). Currently, arrays of chemical treatments are used to preserve fresh produce. However, there are growing health and environmental concern over current practices, due mainly to the risk of generating potentially harmful by-products and residues (Spotts and peters, 1980) which are potential carcinogens; therefore it has created the need to investigate the efficacy of non-traditional sanitizers and other alternative technologies (Selma et al., 2008). One candidate is ozone (Palou et al., 2003; Rice, 1999), a tri atomic oxygen. It is effective in killing microorganisms through oxidation of their cell membranes (Cataldo, 2003). An expert advisory panel asserted the determination that ozone qualified for listing as a Generally Recognized As Safe (GRAS) material (Graham et al., 1997). Ozone has a wide range and a long history as a water disinfectant. Short-term fumigation with 2500 or $5000 \mu \mathrm{ll}^{-1} \times \mathrm{h}$ ozone reduced postharvest gray mold of grapes in storage by approximately 50\% (Mlikota Gabler, et al., 2010). Ozone storage treatment method decreased Botrytis Cinerea contamination of kiwifruits (Barboni, et al., 2010). Comparing with gaseous ozone, treatment of ozonated water was more effective on reduction of aerobic mesophilic bacteria count. Total mold 
count was decreased by $1.7 \mathrm{mgl}^{-1}$ in ozonated water at $7.5 \mathrm{~min}$. and molds were completely inactivated at $15 \mathrm{~min}$ (Zorlugene, et al., 2008). The purposes of this study were to evaluate the effects of ozonated water on the storability and quality-related attributes of 'Bidaneh Qermez', the famous Iranian table grape.

\section{Material and Methods}

\subsection{Plant material}

Table grapes (Vitis vinifera L.), cv. 'Bidaneh Qermez' were harvested randomly from a commercial vineyard located in Takestan, Qazvin, Iran at commercial maturity stage and transported to the laboratory. Grape clusters were divided into small clusters of approximately $300 \mathrm{~g}$ each, those with defects were discarded. Samples were taken every 15 days up to the end of experiment (105 days) and fruits were evaluated at each sampling time after keeping them a day at room temperature.

\subsection{Ozone treatment}

Ozone generator (Model MHP1H, France) was used to produce $0.3 \mathrm{ppm}$ ozone concentration in water. The current Threshold Limit Value-Short Term Exposure Limit (TLV-STEL) for ozone is $0.3 \mathrm{ppm}$ for 15 min as recommended by the American Conference of Governmental Industrial Hygienists (ACGIH) and approved by federal Occupational Safety and Health Administration (OSHA) (Xu, 1999). The output of ozone generator in water was monitored with ozone test kits for ozone concentration. Grape clusters (300g) were dipped into ozonated water for 5, 10, 15 min prior to storage and air dried. Then were placed in polyethylene bags and stored for 105 days at $4^{\circ} \mathrm{C}$ and $75 \%$ Relative Humidity (RH). Control fruits were dipped into non-ozonated water for 5 , $10,15 \mathrm{~min}$ and stored in the same conditions as above samples. All the experiments with $\mathrm{O}_{3}$ were made in the laboratory of Science and Research Branch at Azad University (Tehran, Iran). Measurements were made at room temperature.

\subsection{Weight loss percentage}

The effect of ozone exposure on table grape weight loss was also investigated. Weight of individual bunches was recorded at the beginning of harvest and different sampling times and expressed as percentage of original weight (Valero, et al., 2006).

\subsection{Color changes}

Color changes of berries were analyzed on the skin surface with a Minolta Chromameter CR400, JAPAN. Color was measured at the further two points apart on the equator of each berry and expressed as Chroma $(\mathrm{C}=$ $[(\mathrm{a} 2+\mathrm{b} 2) 0.5])$ and Hue angle $\left(\mathrm{H}^{\circ}=\tan -1\left(\mathrm{~b}^{*} / \mathrm{a}^{*}\right)\right)$ (Valero, et al., 2006).

\subsection{Vitamin $C$ content}

The content of vitamin $\mathrm{C}$ was determined using indophenol procedure. $10 \mathrm{ml}$ of samples were filterated and titrated against sodium 2, 6-dichlorophenol indophenol dye to a faint pink color which persisted for 5-10 seconds. It was expressed as $\mathrm{mg}$ vitamin $\mathrm{C} / 100 \mathrm{~g}$ fruit weight (Titer $\times$ dye equiv. $\times$ dilution $\times 100 /$ Wt. of sample) (Saini et al., 2006).

\subsection{Reducing sugars content}

Reducing sugar was measured with the procedure of Lane-Eynon. Mixed Fehling's solution was made by transferring $5 \mathrm{ml}$ of solution A and $5 \mathrm{ml}$ of solution B to a $250 \mathrm{ml}$ conical flask and mixed well. Diluted fruit juice added to mixed Fehling's solution drop by drop. Then heated over Bunsen burner and boiled for two minutes and then three drops of methylene blue indicator was added (Saini et al., 2006).

\subsection{Decay analysis}

Percent of decay was scored on a 1-9 scale, where: $0=$ intact fruit, $1=$ less than $10 \%$ Decay, $2=$ between $10-20 \%$ decay, $3=$ between $20-30 \%$ decay, $4=$ between $30-40 \%$ decay, $5=$ between $40-50 \%$ decay, $6=$ between $50-65 \%$ decay, $7=$ between $65-80 \%$ decay, $8=$ more than $80 \%$ decay (Nigro, et al., 2000).

\subsection{Berry abscission, cracking and dehydration of rachis}

Berry abscission was scored on a 1-5 scale, where: $1=$ very low, $2=$ low, $3=$ moderate, $4=$ high, $5=$ very high. For the rachis, symptoms of dehydration and browning for primary and secondary branches were evaluated on a ranked scale of $1-5$, where $=1=$ green and fresh, $2=$ green, $3=$ semi-dry, $4=50 \%$ dry, $5=$ absolutely dry (Valero, et al., 2006; Xu, et al., 2007). Number of cracked berries in $1 \mathrm{~kg}$ were evaluated (Xu, et al., 2007).

\subsection{Sensory evaluation}

Sensory analyses to compare the quality of treated and control table grapes were carried out by a 10 trained adults aged 25-40 years. It was about aroma, taste, firmness, appearance and texture. Panelists scored grapes 
between 1-10. 10 being the best total quality and 1 being the worst (Martinez-Romero, et al., 2007). Samples were scored for overall quality by using an interval hedonic scale. Assessments were continued until fruits condition were considered unacceptable.

\subsection{Statistical analysis}

Statistical analysis of the data obtained in the present study was carried out using split factorial method in a completely randomized design layout with 3 replicates. Data obtained were subjected to analysis of variance (ANOVA). Means were separated by SNK and LSD test.

\section{Results and Discussion}

\subsection{Decay analysis}

During the storage period, the incident of berry decay was increased (Table 1). The controls showed $2.56 \%$ of decay while it was just $1.12 \%$ for ozone treated samples. Increasing of treatment time with ozone from 5 to 15 min resulted in an increased resistance to decay (Fig. 1). Use of ozone with 2500 and $5000 \mu \mathrm{LL}^{-1}$ concentrations could control Botrytis cinerea in grapes up to $50 \%$ (Mlikota Gabler, et al., 2010). Use of ozone with $5000 \mathrm{mgL}^{-1}$ concentration in strawberry has been effective in reducing fungal and yeast infections (Allende, et al., 2007). Ozone can be effective in stimulating the production of phytoalexins within the plant, which increase the plant's resistance to decadence accordingly and have high antioxidant role (Sarig, et al., 1996).

\subsection{Reducing sugars content}

While time elapsed, reducing sugars rate was increased form $13.92 \%$ at the harvest time to 17.05 in the $105^{\text {th }}$ day (Table 1). A significant increase in reducing sugars rate was experienced in ozone treated samples compared to the controls. The mean difference between these two groups was 0.76 . Result showed that increase in ozone treating period led to an increased reducing sugars rate (Fig. 2). Glucose and fructose (reducing sugars) of carrots which were treated by ozone $50 \pm 10 \mathrm{nLL}^{-1}$ increased slowly and linearly during a month storage (Hildebrand, et al., 2008). Sugars in tomatoes which were treated with ozone with concentrations of 0.15 and $1.0 \mu \mathrm{molmol}^{-1}$ increased significantly compared with controls (Tzortzakis, 2007). The amount of glucose in strawberries treated by ozone $\left(156 \mu \mathrm{gm}^{-3}\right)$ did not have any significant changes, but the amount of fructose in fruits decreased (Keutgen and Pawelzik, 2008). Increase in reducing sugars is a physiological response which works as a signal (Rolland, et al., 2006). Sugars have little antioxidant action but control antioxidant systems. It can be concluded that the increase in reducing sugars can enhance plant resistance against pathogens, because it can affect the total antioxidant content of fruit. In general, it has been shown that due to the high oxidative capacity of $\mathrm{O} 3$ and its ability to generate toxic agents, they elicit plant defense reactions such as the production of phytoalexins including resveratrol in grapes (Sarig et al., 1996; Allende et al., 2007).

\subsection{Weight loss}

Ozone treatment decreased the weight loss of samples noticeably. Weight loss of ozone treated samples was $0.06 \%$ less than that of control samples. Meanwhile the use of $15 \mathrm{~min}$ ozone treatment had a significant effect on samples water loss (Fig. 3). It seems the life of fresh grapes is considered under the influence of berries and cluster's weight loss. Sample weight loss happens due to water loss and the reduction in stored materials in the process of respiration. Ozone leads to increased dehydration of samples only if it is used in high concentrations which cause damage to epidermis and cuticle tissues of the fruit (Palou, et al., 2002).

\subsection{Color changes}

The Hue angle decreased with increasing storage duration (Table 1). The ozone treated samples had a lower $\mathrm{H}^{\circ}$ compared to control samples (Fig. 4). The Chroma reduced in the storage period (Table 1). Ozone treatment led to a lower Chroma compared to that of the control samples (Fig. 5). It appears that when the samples experience weight loss and dehydration during the storage period, the phenomenon of browning berries occurs and cause more color changes in them. Reduction in the amount of green pigment over time is the main index of berry color purity reduction (Artes-Hernandez and Aguayo, 2004). It seems that in ozone treated samples more green pigments were reduced.

\subsection{Berry abscission and dehydration of rachis}

Ozone treated samples had a lower berry abscission in comparison to the controls. The most berry abscission in ozone treated samples was observed with 5 and 10 min ozone treatment (Fig. 6). Results showed that dehydration of rachis increased during the storage period (Table 1). This increase was lower in ozone treated samples compared to controls. The 15-min ozone treated samples preserved the freshness of their rachis much better than other samples (Fig. 7). Grapes which were treated by $0.1 \mathrm{mgg}^{-1}$ ozone for 20 to 40 min experienced 
no damage to the rachis during the storage period (Sarig, et al., 1996). Table grapes, which were treated by 0.3 ppm ozone, had no damage to their rachis in the storage period (Palou, et al., 2002).

\subsection{Berry cracking and fruit quality}

Ozone treated samples experienced a less berry cracking compared to control samples, so that their mean difference was $212.2 \mathrm{~kg}$. Berry cracking of the 15 -min ozone treated samples was $20.5 \mathrm{~kg}$ less than other ozone treated samples (5 and $10 \mathrm{~min}$ ) (Fig. 8). Because polyethylene package performs as a barrier against water vapor escape, it condenses the water vapor in the package atmosphere on the surface of the fruit and leads to re-absorption of water, this re-absorption could cause berry cracking. It seems ozone treating led to reduction in water loss. Appearance of ozone treated berries was free from all damages (Mlikota Gabler, et al., 2010).

The quality of the fruit was affected in the storage period, controls were infected in the first 15th days, accordingly we failed to compare them with the other samples in the 15th day, but those samples which experienced $15 \mathrm{~min}$ of ozone treatment preserved a better quality compared to other samples, but the difference was not statistically significant (Fig. 9). Most panelists chose the ozone treated (with concentration of 0.15 $\mu \mathrm{molmol}^{-1}$ ) tomatoes regarding appearance and sensory evaluation (Tzortzakis, 2007).

According to our results, ozone treatment did not affect the vitamin C content in a significant manner (Fig. 10). Similar findings are reported in tomato fruits treated with ozone (Shalluf et al., 2007; Tzortzakis, 2007).

\section{References}

Allende, A., Marin, A., Buendia, B., Tomas-Barbean, F., \& Gil, M.I. (2007). Impact of combined postharvest treatments (UV-C light, gaseous $\mathrm{O}_{3}$, super atmospheric $\mathrm{O}_{2}$ and high $\mathrm{CO}_{2}$ ) on health promoting compounds and shelf-life of strawberries. Postharvest Biol. Technol, 46:201-211. http://dx.doi.org/10.1016/j.postharvbio.2007.05.007

Artes-Hernandez, F., \& Aguayo, E. (2004). Alternative atmosphere treatments for keeping quality of Autumn Seedless table grapes during long term cold storage. Postharvest Biol. Technol., 31:59-67. http://dx.doi.org/10.1016/S0925-5214(03)00116-9

Barboni, T., Cannac, M., \& Chiaramonti, N. (2010). Effect of cold storage and ozone treatment on physiochemical parameters, soluble sugars and organic acids in Actinidia deliciosa. Food Chem., 121:946-951. http://dx.doi.org/10.1016/j.foodchem.2010.01.024

Cataldo, F. (2003). On the action of ozone on proteins. Poly. Deg. Stab., 82:105-114. http://dx.doi.org/10.1016/S0141-3910(03)00170-8

Graham, D.M., Pariza, M., Glaze, W.H., Newell, G.W., Erdman, J.W., \& Borzelleca, J.F. (1997). Use of ozone for food preservation. Food Technol., 51:72-76.

Hildebrand, P.D., Forney, C.F., Song, J., Fan, L., \& McRae, K. B. (2008). Effect of a continuous low exposure $\left(50 \mathrm{nll}^{-1}\right)$ on decay and quality of stored carrots. Postharvest Biol.Technol., 49:397-402. http://dx.doi.org/10.1016/j.postharvbio.2008.03.012

Hulea, A., Tasca, Gh., \& Beratlief, C. (1982). Bolile Si daunatorii produselor agricole si hortiviticole dupa recoltare. Ed. Ceres. Buc., 193-210.

Keutgen, A.J., \& Pawelzik, E. (2008). Influence of pre-harvest ozone exposure on quality of strawberry fruit under stimulated retail conditions. Postharvest Biol. Technol, 49:10-18. http://dx.doi.org/10.1016/j.postharvbio.2007.12.003

Mari, M., Bertalini, P., \& Pratella, G.C. (2003). Non-conventional methods for the control of postharvest pear disease. J. Appl. Microbiol., 94:761-766. http://dx.doi.org/10.1046/j.1365-2672.2003.01920.x

Martinez-Romero, D., Guillen,F., Valverde, J.M., Bailen, G., Zapata, P.J. \& Serrano, M. (2007). Influence of carvacrol on survival of Botrytis cinerea inoculated in table grapes. Inter. J. Food Microbiol., 115:144-148. http://dx.doi.org/10.1016/j.ijfoodmicro.2006.10.015

Mlikota Gabler, F., Smilanick, J.L., Mansour, M.F., \& Karaca, H. (2010). Influence of fumigation with high concentrations of ozone gas on post-harvest gray mold and fungicide residues on table grapes. Postharvest Biol. Technol., 55:85-90. http://dx.doi.org/10.1016/j.postharvbio.2009.09.004

Nigro, F., Ippolito, A., Lanttanzio, V., Di Venere, D., \& Salerno, M. (2000). Effect of ultraviolet-C light on postharvest decay of strawberry. J. Plant Pathol., 82:29-37.

Pak, H.A., \& Dixon, J. (2001). Postharvest treatment with ozone for the control of Ripe rots in Avocado. NZ Avocado Growers Assoc. Ann. Res. Rep. 1. 
Palou, L., Smilanick, J.L., Crisosto, C.H., Mansour, M., \& Plaza, P. (2003). Ozone gas penetration and control of the sporulation of Penicillium digitatum and Penicillium italicum within commercial packages of oranges during cold storage. Crop Prot., 22:1131-1134. http://dx.doi.org/10.1016/S0261-2194(03)00145-5

Palou, L., Crisosto, C.H., Smilaneck, J.L., Adaskaveg, J.E., \& Zoffoli, J.P. (2002). Effects of continuous 0.3 ppm ozone exposure on decay development and physiological responses of peaches and table grapes in cold storage. Postharvest Biol. Technol., 24:39-48. http://dx.doi.org/10.1016/S0925-5214(01)00118-1

Rice, R.G. (1999). Ozone in the United states. Ozone Sci. Eng., 21:99-118. http://dx.doi.org/10.1080/01919519908547244

Rolland, F., Gonzalez, E., \& Sheen, J. (2006). Sugar sensing and signaling in plants: Conserved and Novel Mechanisms. Annu. Rev. Plant Biol., 57:675-709. http://dx.doi.org/10.1146/annurev.arplant.57.032905.105441

Saini, R.S., Sharma, K.D., Kaushik, R.A., \& Dhankhar, O.P. (2006). Laboratory manual analytical techniques in horticulture. Agrobios (India). IST Edition 12-26.

Sarig, P., Zahavi, T., Zutkhi, Y., Yannai, S., Lisker, N., \& Ben-Arie, R. (1996). Ozone for control of postharvest decay of table grapes caused by Rhizopus stolonifer. Physiol. Mol. Plant Pathol, 48:403-415. http://dx.doi.org/10.1006/pmpp.1996.0032

Selma, M.V., Ibanez, A.M., Allende, A., Cantwell, M., \& Suslow, T. (2008). Effect of gaseous ozone and hot water on microbial and sensory quality of cantaloupe and potential transference of Escherichia coli $\mathrm{O}_{157}: \mathrm{H}_{7}$ during cutting. Food Microbiol, 25:162-168. http://dx.doi.org/10.1016/j.fm.2007.06.003

Shalluf, M.A., Tizaoui, C., \& Karodia, N. (2007). Controlled atmosphere storage technique using ozone for delay ripening and extend the shelf life of tomato fruit. IOA Conference and Exhibition, Valencia.

Spotts, R.A., \& Peters, B.B. (1980). Chlorine and chlorine dioxide for control of Anjou pear decay. Plant Dis., 64:1095-1097. http://dx.doi.org/10.1094/PD-64-1095

Thumula, P. (2006). Studies on storage behavior of tomatoes coated with chitosan-lysozyme films. Department of Bio Resource Engineering, Faculty of Agricultural and Environmental Sciences. Mc Gill University Montreal, Quebec, Canada. M.S thesis.

Tzortzakis, N.G. (2007). Maintaining postharvest quality of fresh produce with volatile compounds. Inn. Food Sci. Em. Technol., 8:111-116. http://dx.doi.org/10.1016/j.ifset.2006.08.001

Valero, D., Valverde, J.M., Martinez-Romero, D., Guillen, F., Catioo, S., \& Serrano, M. (2006). The combination of modified atmosphere packaging with Eugenol or Thymol to maintain quality, Safety and functional properties of table grapes. Postharvest Biol. Technol., 41:317-327. http://dx.doi.org/10.1016/j.postharvbio.2006.04.011

Xu, L. (1999). Use of ozone to improve the safety of fresh fruits and vegetables. Food Technol., 53: 58-61.

Xu, W.T., Huang, K.I., Guo, F., Qu, W., Yang, J.J., Liang, Z.H., \& Luo, Y.B. (2007). Postharvest grapefruit seed extract and chitosan treatments of table grapes to control Botrytis cinerea. Postharvest Biol. Technol., 46:86-94. http://dx.doi.org/10.1016/j.postharvbio.2007.03.019

Zorlugenc, B., Zorlugenc, F.K., Oztekin, S., \& Evliya, B. (2008). The influence of gaseous ozone and ozonated water on microbial flora and degradation of Aflatoxin $\mathrm{B}_{1}$ in dried figs. Food Chem. Toxicol., 46:3593-3597.

Table 1. The mean of evaluated parameters during the storage period in table grape cv. 'Bidaneh Qermez'

\begin{tabular}{|c|c|c|c|c|c|c|c|c|c|}
\hline Time & Decay & $\begin{array}{c}\text { Weight } \\
\text { loss }\end{array}$ & $\begin{array}{c}\text { Reducing } \\
\text { sugars }\end{array}$ & $\begin{array}{c}\text { Chroma } \\
(\mathbf{C})\end{array}$ & $\begin{array}{c}\text { Hue } \\
\text { angle(H)}\end{array}$ & $\begin{array}{c}\text { Berry } \\
\text { abscission }\end{array}$ & $\begin{array}{c}\text { Berry } \\
\text { dehydration }\end{array}$ & $\begin{array}{c}\text { Berry } \\
\text { cracking }\end{array}$ & $\begin{array}{c}\text { Fruit } \\
\text { quality }\end{array}$ \\
\hline 0 & $0 \mathrm{e}$ & $0 \mathrm{~d}$ & $13.92 \mathrm{f}$ & $9.47 \mathrm{a}$ & $44.9 \mathrm{a}$ & $0 \mathrm{e}$ & $1 \mathrm{~d}$ & $0 \mathrm{c}$ & $10 \mathrm{a}$ \\
\hline 15 & $1.17 \mathrm{c}$ & $0.05 \mathrm{~b}$ & $14.37 \mathrm{e}$ & $9.46 \mathrm{a}$ & $41.5 \mathrm{c}$ & $1.83 \mathrm{c}$ & $2.5 \mathrm{~b}$ & $0 \mathrm{c}$ & $8.6 \mathrm{~b}$ \\
\hline 30 & $2.67 \mathrm{~b}$ & $0.13 \mathrm{a}$ & $15.80 \mathrm{~d}$ & $8.28 \mathrm{~b}$ & $43.5 \mathrm{a}$ & $2.78 \mathrm{a}$ & $3.11 \mathrm{a}$ & $6.4 \mathrm{a}$ & $7.7 \mathrm{c}$ \\
\hline 45 & $0.78 \mathrm{~cd}$ & $0.09 \mathrm{a}$ & $15.26 \mathrm{c}$ & $7.19 \mathrm{~cd}$ & $42.7 \mathrm{bc}$ & $1.67 \mathrm{c}$ & $2.22 \mathrm{bc}$ & $5.6 \mathrm{c}$ & $7.3 \mathrm{~cd}$ \\
\hline 60 & $2.7 \mathrm{~b}$ & $0.1 \mathrm{a}$ & $15.96 \mathrm{~b}$ & $7.26 \mathrm{c}$ & $41.9 \mathrm{c}$ & $2.11 \mathrm{bc}$ & $3.22 \mathrm{a}$ & $10 \mathrm{c}$ & $7 \mathrm{c}$ \\
\hline 75 & $2.83 \mathrm{~b}$ & $0.1 \mathrm{a}$ & $15.95 \mathrm{~b}$ & $7.02 \mathrm{~cd}$ & $43.2 \mathrm{ab}$ & $2.5 \mathrm{ab}$ & $2.5 \mathrm{~b}$ & $28 \mathrm{~b}$ & $6.9 \mathrm{~d}$ \\
\hline 90 & $0.67 \mathrm{~d}$ & $0.02 \mathrm{c}$ & $16.85 \mathrm{a}$ & $6.98 \mathrm{~cd}$ & $43.4 \mathrm{ab}$ & $0.67 \mathrm{~d}$ & $2 \mathrm{c}$ & $0 \mathrm{c}$ & - \\
\hline 105 & $4.33 \mathrm{a}$ & $0.05 \mathrm{~b}$ & $17.05 \mathrm{a}$ & $6.66 \mathrm{~d}$ & $39.7 \mathrm{~d}$ & $0.67 \mathrm{~d}$ & $2.33 \mathrm{bc}$ & $0 \mathrm{bc}$ & - \\
\hline
\end{tabular}




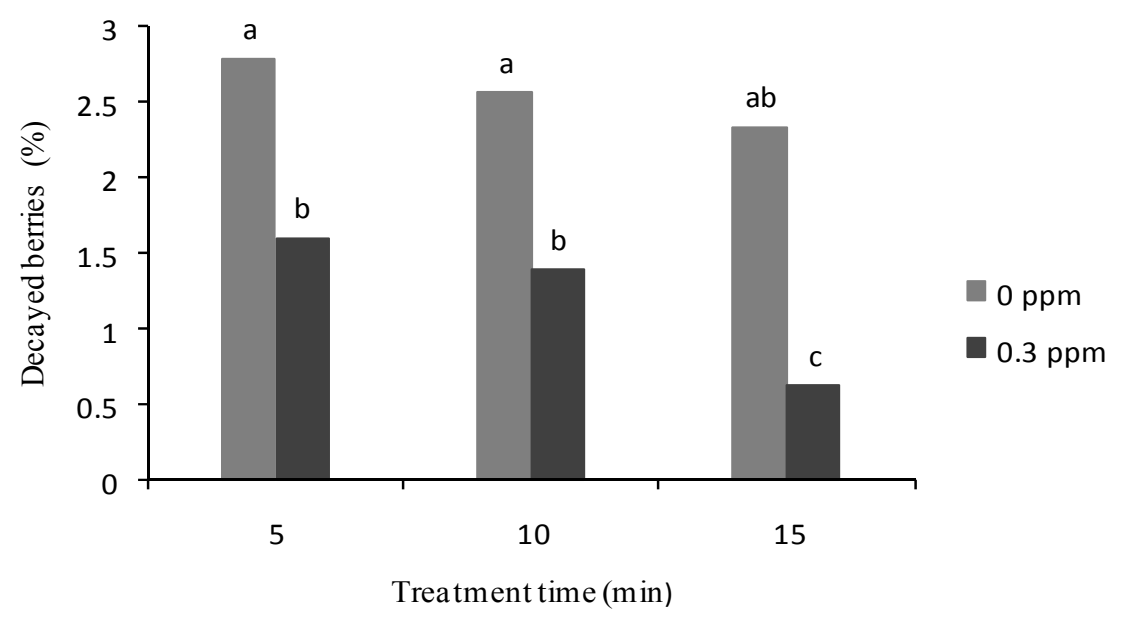

Figure 1. The effect of ozone treatment and treatment time on decayed berries of 'Bidaneh Qermez' table grape

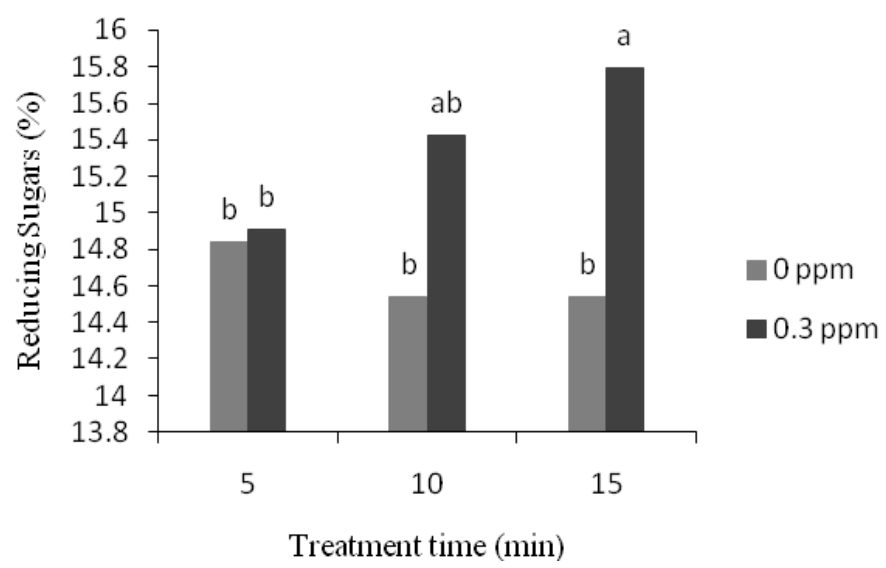

Figure 2. The effect of ozone treatment and treatment time on reducing sugars of 'Bidaneh Qermez' table grape

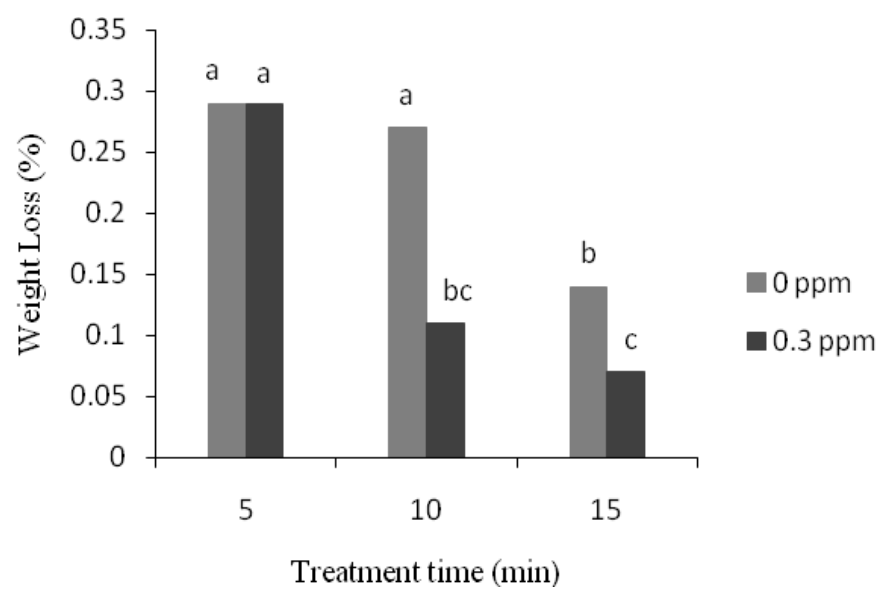

Figure 3. The effect of ozone treatment and treatment time on weight loss of 'Bidaneh Qermez' table grape 


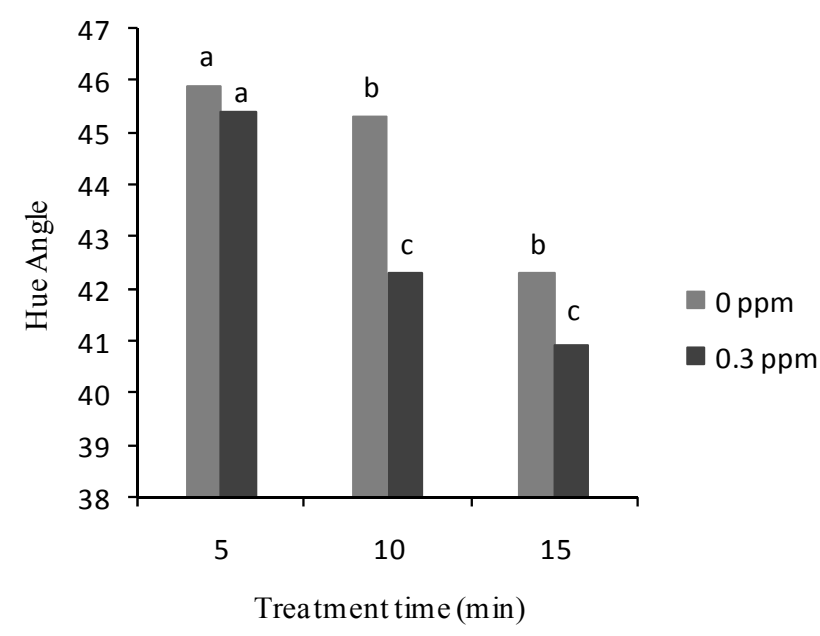

Figure 4. The effect of ozone treatment and treatment time on hue angle of color in 'Bidaneh Qermez' table grape

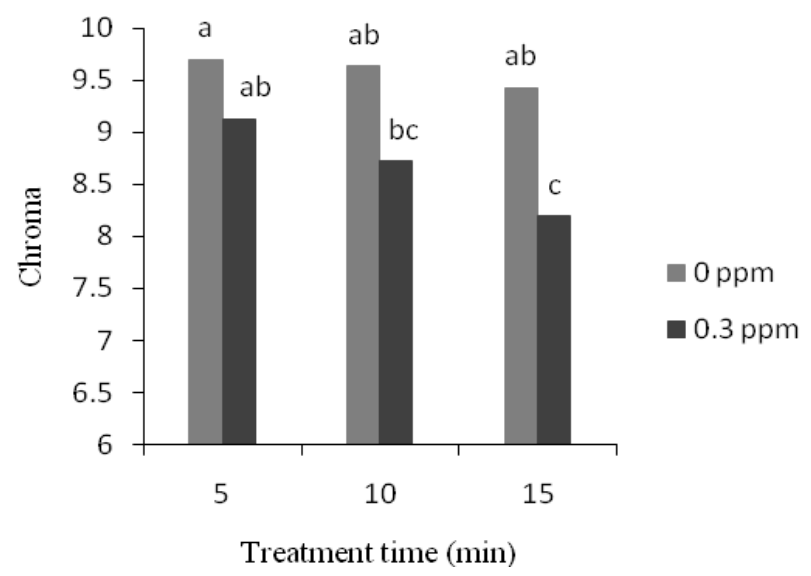

Figure 5. The effect of ozone treatment and treatment time on chroma of color in 'Bidaneh Qermez' table grape

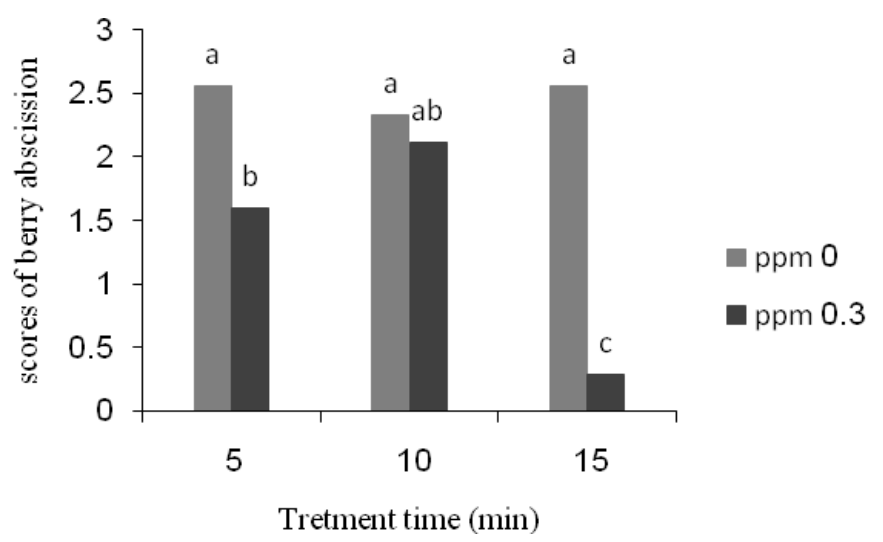

Figure 6. The effect of ozone treatment and treatment time on berry abscission of 'Bidaneh Qermez' table grape 


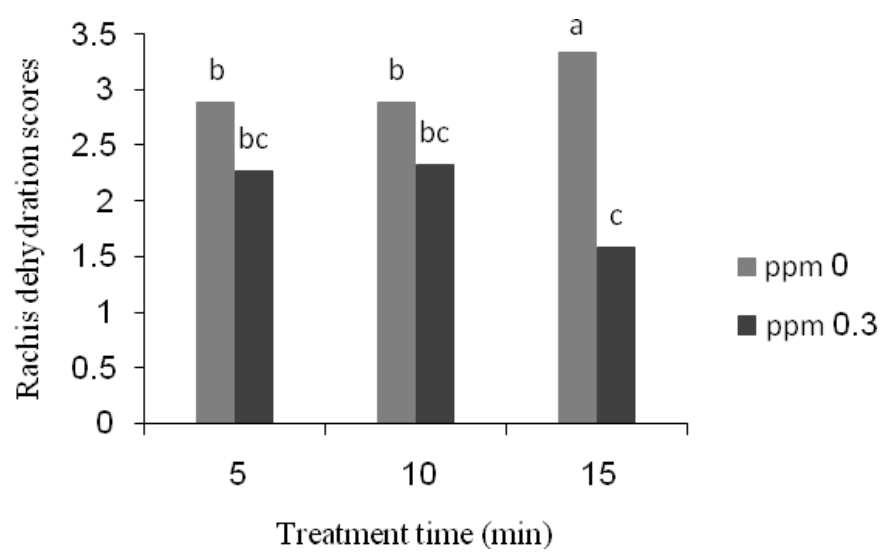

Figure 7. The effect of ozone treatment and treatment time on rachis dehydration of 'Bidaneh Qermez' table grape

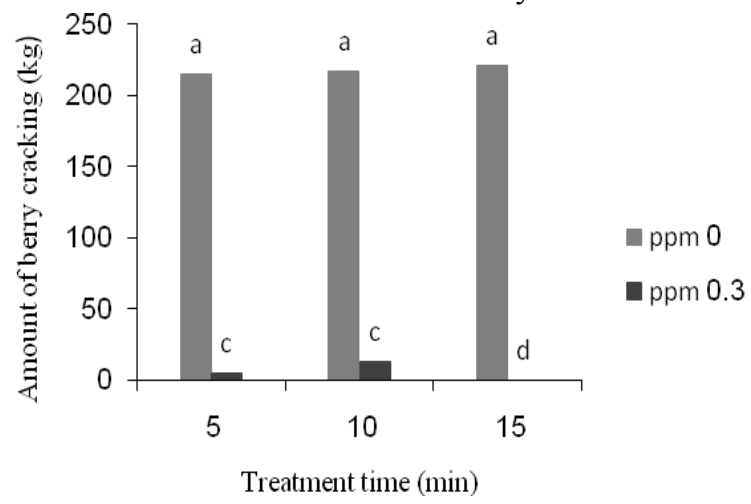

Figure 8. The effect of ozone treatment and treatment time on berry cracking of 'Bidaneh Qermez' table grape

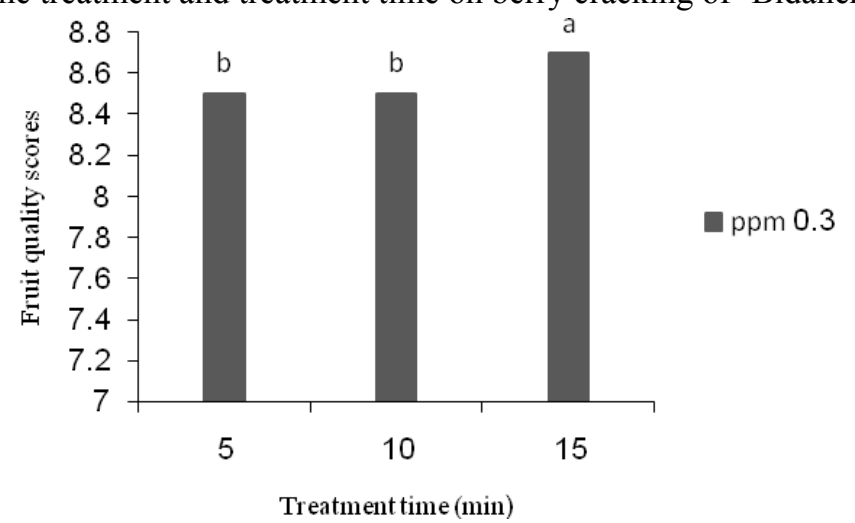

Figure 9. The effect of ozone treatment and treatment time on sensory analysis of 'Bidaneh Qermez' table grape

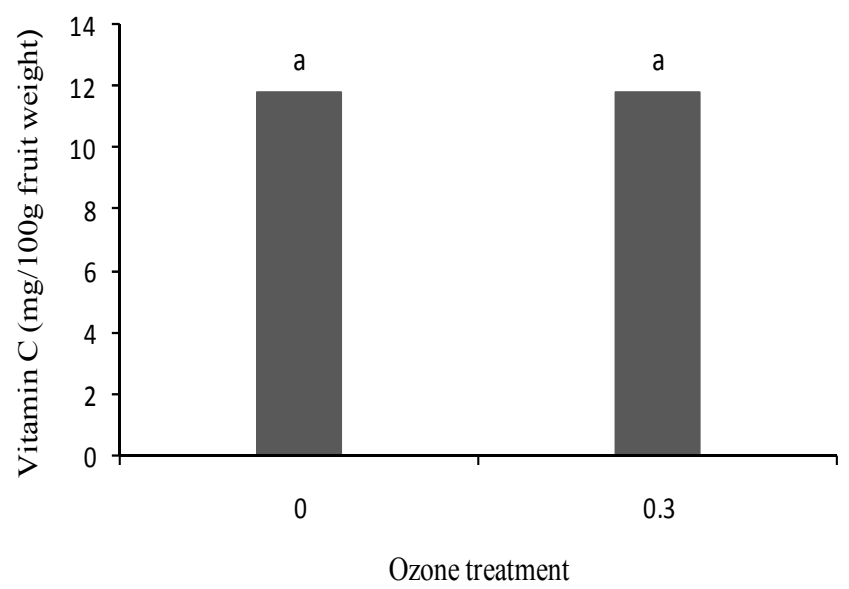

Figure 10. The effect of ozone treatment on vitamin C of 'Bidaneh Qermez' table grape 